\title{
STATE REGIONAL POLICY IN THE SPHERE OF TOURISM IN UKRAINE
}

\author{
Alla Havryliuk \\ PhD in Public Administration, Associate Professor; \\ ORCID: 0000-0003-2743-0409; e-mail: romasha94@ukr.net \\ Kyiv National University of Culture and Arts, Kyiv, Ukraine
}

\begin{abstract}
The article examines the legal principles of the state regional policy in the field of tourism in Ukraine. It is asserted that Ukraine implements national and local programs, strategies and concepts that determine local development of communities taking into account tourist, economic, social, historical, cultural and human resources. It is proposed to improve the legal mechanism of state regulation of the tourism sphere through the introduction of amendments to the Law of Ukraine "On Tourism". These include: formation of the foundations of the local (national, regional, local) identity of the population by means of tourism; establishment of the unity of Ukrainian nation; active cultivation of cultural and spiritual values, etc.
\end{abstract}

Keywords: tourism; tourism sphere; regional tourism policy; socio-humanistic dimension

\section{Formulation of the problem}

Transformation processes transformation processes have a significant impact on the system of state administration of tourism in Ukraine. Regionalism prevails among the priority valuable fundamentals - state policy is aimed at increasing the role of certain territories with the involvement of local resources and areas that determine the main vectors of their development.

Ukraine has a variety of socio-economic, geographical, ethnographic, historical and cultural differences that determine its regional dimension.

Among the spheres of Ukrainian social life, tourism occupies the unique niche that decisively influences the formation of an attractive socio-humanitarian space to meet the needs of individual in recreation, rehabilitation, education, self-development, establishment of civil and national values, promotion of ethnic traditions, etc.

Therefore, the regional tourism policy is now relevant for the Ukrainian state, which, in the conditions of decentralization, creates a favourable basis for finding and popularizing the unique local identity of the territory, is a marker of community initiatives, an image strategy tool, a way of socio-economic development of the territory, etc. 
In accordance with the State Strategy for Regional Development for the period up to 2020 , tourism was recognized as one of the priority objectives of the state regional policy (Vorotin, \& Zhalilo, 2010). This is confirmed by the diversity of historical, cultural, recreational, urban, ethnographic, other domestic tourist resources and the demand of local communities for new forms of development of territories. Tourist regionalization of countries is becoming widespread both in the world and in Ukraine. Therefore, public requests for scientific research on this subject are obvious and relevant, which serve as the basis for implementation of practical actions.

However, not all territorial communities in Ukraine evaluate tourism as a promising resource for the development of territory. There is a small number of initiative people who are capable of generating ideas at the local level; local collective values are not sufficiently formed; lack of experience in effective managerial decisions; there is no desire to go beyond the territorial space in order to promote unique tourist attractions, etc.

At the same time, regional differences in the peculiarities of implementation of state policy in the field of tourism, which should be adapted to the social values of the territory, the community mentality, and, at the same time, fit into the context of the socio-humanistic development of the country, need to be correlated. Namely these key aspects are taken to solve the unresolved parts of the general problem.

\section{Analysis of recent research and publications}

The state policy of regional development management is increasingly becoming the focus of domestic researchers, namely: L. Agafonova, L. Dyadechko, M. Boruschak, L. Didkivska, V. Vorotin, Ya. Zhalilo, A. Chechel, S. Nezdoyminov, V. Semenov et al. Gradually, the regulatory and legal framework of the state regional policy, which fits in peculiarities of the development of local tourism, is being formed.

The following Ukrainian scientists are worth mentioning - V. Kyfyak, Yu. Navruzov, D. Stechenko I. Shkola, T. Tkachenko et al. - who direct their research into the study of economical centric aspects of regional policy of the tourism sphere, which is important. However, consideration of social, ethnic and cultural territorial features of the region, which present its uniqueness and determine local regionalism, should be studied more precisely.

The purpose of the article is to study the legal bases of state policy of regional tourism development taking into account the socio-humanistic factors of the development of territory.

\section{Presenting main material}

As translated from latinregio means a country, a region - a certain territory that has the integrity and interconnection of the constituent elements, and is also used in the sense of the territorial unit of state. The region is distinguished by a number of characteristic features, which are provided as: territorial production structure; integrated economic environment with a predominantly closed production cycle; production of finished products on the basis of regional division of labour; the 
integrated connection, transport and economic system; relative independence of management within the framework of single production complex, provided with its own labour, material and financial resources; regional market for goods and labour, market infrastructure, etc (Izha, 2011, p. 10).

For European institutions, the term "region" is a "direct subordinate level after the state" (local, district (territorial) and regional). In 1996 the Assembly of European Regions adopted the Declaration on Regionalism and considers the region as "territorial entities formed by law in an established manner, with the lower level than those of the state and endowed with political self-government" (Nezdoiminov, 2009, p. 9).

Currently, the definition of "tourist region" is often used. The scientist M. Boruschak (2014) suggests to consider it as a geographic area, which is chosen by a tourist for the purpose of a certain tourist visit. This area contains all the facilities necessary for staying, living, meals and organizing leisure activities for tourists. The region is the sole tourist product and competitive unit and should be managed as a strategic commercial unit (Izha, 2011, p. 67).

Thus, the tourist region is an area of tourist interest, offering a certain set of services necessary to meet the needs of tourists. A city, a district, a resort, and the whole country, or even a group of countries that a tourist chooses according to the purpose of his trip can be considered as the tourist region.

As we see, there is no single definition of "region", but it is a clearly structured subsystem of the socio-economic system of the country, which is interested in achieving national goals of the country's strategic development, has autonomy of interests that are determined by economic, geographical, political, socio-cultural and other features of the territory.

What are the legal bases of the state policy of tourism development in the region?

The state policy of regionalization in Ukraine has received institutional and legal reload since the proclamation of the country's course on decentralization. In the context of changing the paradigm of regional policy, the role of actors in the implementation of this policy, namely local government executive bodies, as well as local self-government bodies as local government structures, which together act as powerful coordinating centres for the development of territories, is growing. Since then, there is a reset of the thinking of communities, institutions of regional development in relation to tourism. A significant number of regions of the country choose tourism as a priority area of development of the territory.

The main legal principles of implementation of the state regional policy are laid down in the State Strategy of Regional Development of Ukraine; action plan for implementation of the State Strategy for Regional Development of Ukraine; regional development strategies; plans of measures for the implementation of regional development strategies; investment programs (projects) aimed at the development of regions (On Tourism, 1995).

The region, from the point of view of the interests of regional tourism, is a spatial substance, where the objects of tourist interest and the infrastructure serving the tourists are concentrated; the socio-economic complex concentrates, which ensures the sustainable development of tourism through the implementation, formation and 
management of the tourist destination (translation from English - destination / place of arrival of a tourist).

The development of regional tourism affects the restoration of vitality of the local population and tourists; determines its functioning as an independent economic complex, which ensures employment of the population and the receipt of additional income in the region; is a factor in preserving the ethnic and cultural and naturerecreational competitive potential of the territory.

Therefore, the object of management of regional development of tourism will be the territory, the region; the subject is the local government, and the goal is to achieve a high level of development of a specific regional education (in accordance with the Constitution, laws, statutes of territorial communities, and other legislative acts of Ukraine. The subject matter is the regional economy and all the processes that are affected by tourism: formation of a local tourist product, interaction with local government bodies; formation and development of market relations, participation in the implementation of reforms, formation of local identity, etc.

However, the regional administration is not limited to the activities of territorial units of the central bodies of state power, local state administrations and local selfgovernment bodies of the region, but also includes the actions of its inhabitants and local elites aimed at solving local socio-economic, ethnic and cultural problems.

The Law of Ukraine "On the Principles of State Regional Policy" (2015) (hereinafter referred to as the Law) defines legal, economic, social, ecological, humanitarian and organizational foundations of the state regional policy as an integral part of Ukraine's domestic policy. In particular, the document defines the purpose, principles and priorities of the state regional policy, the powers of its subjects, financial support instruments and monitoring.

It is notable that the Law defines the following principles of regional development, which are priorities for the socio-humanistic component of tourism, namely: historical succession (taking into account and preserving the positive achievements of previous development of the regions); ethnic and cultural development (the revival of ethnic consciousness and preservation of the spiritual and material culture of ethnic groups, promotion of their ethnic, cultural, linguistic and religious identity); sustainable development (development of society to meet the needs of the present generation, taking into account the interests of future generations) (On Tourism, 1995).

At the same time, the Law of Ukraine "On Tourism" states that the state recognizes tourism as a priority direction of development of economy and culture; however, the issues concerning socio-humanistic vector of tourism development and legal bases of its realization in the context of state policy in the tourism sphere in general are still not regulated.

Now there are two draft laws developed by the Parliamentary Committee on Family, Youth Policy, Sports and Tourism and the Department of Tourism and Resorts of the Ministry of Economic Development and Trade of Ukraine in the domestic legal field of tourism. They cover a multi vector vision of the future development of tourism in the country, which, unfortunately, does not affect the socio-humanistic problems of the sphere (On Amendments to the Law of Ukraine, 2018; Cabinet of Ministers of Ukraine, 2014). Out of two documents, only the deputative outline the new perspectives for 
priority development of the sphere - the declaration of domestic and inbound tourism as strategic forms of tourism in the country and the directions of development of economy and culture that will create conditions for the development of tourism industry, tourism security and protection of tourist objects (Cabinet of Ministers of Ukraine, 2014).

We do not see the socio-humanistic vectors of development of the sphere in the Strategy for Development of Tourism and Resorts for the period up to 2026. The purpose of the document focuses on creating favourable conditions for the development of tourism and resorts in accordance with international standards of quality and taking into account European values, transforming the sphere into a high-quality competitive, integrated world market industry, development of regions and the state as a whole, improvement of the quality of life of the population, harmonious development and consolidation of society, popularization of Ukraine in the world (Cabinet of Ministers of Ukraine, 2017). Although, it would seem that such a state position quickly covers this area of the problem, but there is no supporting tasks and directions for its implementation in the document.

- A positive fact is the inclusion to the State Strategy for Regional Development for the period up to 2020 of issues related to the regional development of tourism. The legal act defines objectives of the state regional policy and the main tasks of central and local executive authorities and local governments aimed at achieving these goals, and also provides for the coherence of the state regional policy with other state policies aimed at territorial development (On Amendments to Some Legislative Acts, 2018).

The priority goals of the State Strategy for Regional Development are the following:

- improving competitiveness of the regions (goal 1): development of rural areas, stimulation of employment of the population outside the sphere of agricultural production, including the development of agrarian business, rural tourism, folk crafts, service-oriented companies, collection and processing of wild berries and mushrooms, medicinal raw materials, etc.; creation of conditions for social development of the village, sustainable motivation to social responsibility of business in the agrarian sector, related sectors of production and services;

- rational use of natural resource potential, preservation of cultural heritage and the most valuable natural territories (goal 2): raising the level of awareness of the population regarding the values of territories and objects of the nature reserve fund and attracting the population to their management; preservation of historical and cultural values and natural heritage, provision of access to cultural and natural heritage in regions; attraction of investments in creation of electronic catalogues of museum exhibits, monuments of history and monumental art, architecture, archaeology; creation of conditions for preservation in the regions of distinctive folk culture, customs, traditions, rituals, including those of the national minorities; the use of cultural heritage objects for tourism activities; development of green tourism in the countryside; improvement of the regulatory framework for the development of tourism and resorts, in particular by developing and approving the state target program for the development of tourism and resorts of Ukraine for the period up to 2022; creation of high-quality tourism product on the basis of rational use of tourist resources, definition of zones of priority development of tourism by way of tourist zone division of regions; 
formation of a positive image of regions in the field of tourism on the external and internal tourism market; creation of a national information network in the field of tourism and resorts, in particular by developing an appropriate network of information centres in the regions;

- socio-cultural development (goal 3): formation of a basic network of cultural institutions in all regions; development and preservation of the existing network of institutions of culture, art and museum studies; ensuring the proper functioning of rural cultural institutions, providing cultural services to residents of villages and small towns; promoting consolidation and development of the Ukrainian nation, ensuring rights to freedom of opinion and religion of citizens, in particular, national minorities, etc (On Amendments to Some Legislative Acts, 2018).

\section{Conclusions}

Having analysed the legal principles of socio-humanistic dimension of the state regional policy in the sphere of tourism in Ukraine, it has been found that this aspect is covered in different ways in the legal field of region studies and tourism. It deserves approval that the development of tourism in certain regions is recognized as a strategic priority of the state policy of development of territories, its social value principles, community mentality and fits into the context of the socio-humanistic development of the country and domestic policy of the state. We already have existing national and regional strategies, concepts, programs, etc., which determine the local development of territories, taking into account tourist, economic, social, historical, cultural and human resources. However, this aspect remains insufficiently considered in the legal field of tourism.

In view of this, we consider it urgent to amend the current domestic legislation regulating the development of tourism in Ukraine. The introduction of amendments to Section II "State Policy and State Regulation in the Sphere of Tourism" of the Law of Ukraine "On Tourism", which deals with the main priorities of state policy in the field of tourism is among the strategic objectives. These include: formation of the foundations of the local (national, regional, local) identity of the population by means of tourism; establishment of the unity of Ukrainian nation; active cultivation of cultural and spiritual values, etc.

As a result, understanding of the goals and objectives of the state policy in the sphere of tourism should be based on the axiological approach to implementation of the state regional policy in Ukraine and the improvement of legal mechanism of state regulation of the sphere. Subsequently, this problem will serve as the basis for conducting scientific research.

\section{References}

Asambleia yevropeiskykh rehioniv. Deklaratsiia shchodo rehionalizmu $v$ Yevropi [Assembly of European Regions. Declaration on regionalism in Europe]. (1996). Retrieved from https://constituanta.blogspot.com/2013/03/1996.html [in Ukrainian]. 
Borushchak, M. (2014). Problemy formuvannia stratehii i rozvytku turystychnykh rehioniv [Problems of formation of the strategy of development of tourist regions] [Monograph]. Lviv: Instytut rehionalnykh doslidzhen NAN Ukrainy [in Ukrainian].

Cabinet of Ministers of Ukraine. (2014). On Approval of the Public Strategy regional development for the period up to 2020. Resolution dated August 6, 2014, No. 385. Retrieved from https://www.kmu.gov.ua/ua/npas/247566248 [in Ukrainian].

Cabinet of Ministers of Ukraine. (2017). On approval of the Tourism Development and Resorts Strategy for the period up to 2026. Order dated March 16, 2017, No. 168-p. Retrieved from http://zakon2.rada.gov.ua/laws/show/168-2017-\%D1\%80 [in Ukrainian].

Izha, M.M. (2011). Systema rehionalnoho upravlinnia: svitovyi dosvid i Ukraina [System of regional management: world experience and Ukraine] [Monograph]. Odesa: Drukarskyi dim [in Ukrainian].

Nezdoiminov, S.H. (2009). Turyzm yak faktor rehionalnoho rozvytku. Metodolohichnyi aspekt ta praktychnyi dosvid [Tourism as a factor of regional development: methodological aspect and practical experience] [Monograph]. Odesa: Astroprynt [in Ukrainian].

On Amendments to Some Legislative Acts of Ukraine on Tourism. (2018). Law Project. Retrieved from http://www.me.gov.ua/Documents/Print?lang=uk-UA\&id=b655207f-17e1-4a6598f5-2c649445e716 [in Ukrainian].

On Amendments to the Law of Ukraine "On tourism" on Improvement of the State Policy in the Tourism Sphere. (2018). Law Project dated April 20, 2018, No. 8317. Retrieved from http://w1.c1.rada.gov.ua/pls/zweb2/webproc4_1?pf3511=63927 [in Ukrainian].

On the Principles of State Regional Policy. (2015). Law of Ukraine dated February 5, 2015, No. 156-VIII. Retrieved from http://zakon3.rada.gov.ua/laws/show/156-19 [in Ukrainian].

On Tourism. (1995). Law of Ukraine dated September 15, 1995, No. 324/95-BP. Retrieved from https://zakon.rada.gov.ua/laws/show/324/95-\%D0\%B2\%D1\%80 [in Ukrainian].

Vorotin, V.Ye., \& Zhalilo, Ya.A. (Eds). (2010). Derzhavne upralinnia rehionalnym rozvytkom Ukrainy [Public administration of regional development of Ukraine] [Monograph]. Kyiv: Natsionalnyi instytut stratehichnykh doslidzhen [in Ukrainian].

\section{ДЕРЖАВНА РЕГІОНАЛЬНА ПОЛІТИКА У СФЕРІ ТУРИЗМУ УКРАЇНИ}

\section{Алла Гаврилюк}

Кандидат наук з державного управління, доцент; ORCID: 0000-0003-2743-0409; e-mail: romasha94@ukr.net

Київський національний університет культури і мистецтв, Київ, Україна

\section{Анотація}

У статті розглянуто правові засади державної регіональної політики у сфері туризму в Україні. Доведено, що Україна реалізує національні та місцеві програми, стратегії 
та концепції, що визначають місцевий розвиток громад з урахуванням туристичних, економічних, соціальних, історичних, культурних та людських ресурсів. Запропоновано вдосконалення правового механізму державного регулювання сфери туризму шляхом внесення змін до Закону України «Про туризм». До них належать: формування основ місцевої (національної, регіональної, місцевої) ідентичності населення засобами туризму; створення єдності української нації; активна культивація духовних і культурних цінностей тощо.

Ключові слова: туризм; туристична сфера; регіональна туристична політика; соціально-гуманістичний вимір 